\title{
Correction to: Preliminary assessment approach to predict seismic vulnerability of existing low and mid-rise RC buildings
}

\section{Hakan Dilmaç ${ }^{1}$}

Published online: 16 March 2020

(c) Springer Nature B.V. 2020

\section{Correction to: Bulletin of Earthquake Engineering} https://doi.org/10.1007/s10518-020-00809-z

This erratum is published as several corrections were overlooked during typesetting. The original article has thus been updated with the corrections.

The original article can be found online at https://doi.org/10.1007/s10518-020-00809-z.

Hakan Dilmaç

hakandilmac@sdu.edu.tr

1 Department of Civil Engineering, Suleyman Demirel University, Isparta, Turkey 